\title{
Ben Agger was a Blazing Intellect
}

\author{
Stephen Turner
}

Ben Agger was a blazing intellect, whose work provides important lessons-moral lessons, if that is not too pretentious - about the life of the mind and the way to live it. I was made aware of Ben by John O’Neill, who in his usual off-hand way mentioned that he might interest me. I met him only when he was an assistant professor at Buffalo, in the hall during an ASA meeting. We instantly took a liking to each other. He was almost exactly my age, and full of life and intensity. We had a bond, of an odd kind that bears directly on the lessons of his life. We were outsiders, both "sociological theorists" at a time when the field was in a peculiar kind of flux: the best of times and the worst of times. The best part was this: the 1970s, in which we were formed, saw the end of two hegemonic empires, those of Parsons and Merton. It also saw the digging of the grave of sociological positivism. This opened up a range of possibilities, not the least of which was the one Ben seized: the application of literary theory. The worst parts were the remaining hangovers from the past.

Ben was a precocious participant in the wide-ranging debates of the early seventies. He gave his first paper in Dubrovnik in 1972, "Of Style and Speech in the New Age," signaling a lifelong interest. He attended, as I did, the 1974 World Congress of Sociology in Toronto, and published a scathing critique of it, attacking the narcissism of sociologists' self-congratulation about being scientific, noting the often amusing confrontation of East and West at a time when the Communist bloc countries treated these international meetings as carefully watched contests between their side and the Western other, and calling for an engaged sociology in the style of C. Wright Mills.

The critique reflected what were to be lifelong commitments. But it is important to know what they meant at the time, and how the experience of the time formed him. At the time of this meeting, the official structures, especially in the US, were still dominated by the near-retirement students of Talcott Parsons and Robert Merton, who were eager to pass the mantle on to the like-minded, of which there were very few. Generational conflict was intense. In Toronto there were testy exchanges with older sociologists, some of whom had careers dating back to the 1930s and were on their last mission.

We, however, had youth on our side. Our opponents were a cartel, powerful, but at the end of the line. Nothing made this clearer than the volume officially sanctioned by the ASA called Approaches to the Study of Social Structure (1975), on what was taken to be the core intellectual contribution of this cartel and the core of sociology and sociological theory, but what amounted to a festschrift for Merton. It was edited by his acolyte Peter Blau, already in his late fifties, and came out of these same meetings. To this might be added Merton's own paper justifying his career (1975), written at the Center for Advanced Study in the Behavioral Sciences. Many of these papers, and Merton himself, struggled to differentiate Merton's "structuralism” from plain structural functionalism, and failed. They were clearly on the defensive. Yet there was to be one last great gasp from this generation, which had deep consequences, and to which I will return shortly.

In the intellectual milieu in which Ben was formed, the battle lines were clear, and it was also clear that they were battle lines. Ben took a position on the Left flank of the new generation. In the period between these meetings and 1982, a year whose significance will become clear, he published a book and nine articles or chapters, several of which were in highly respectable places, including two in Polity, and two in Dialectical Anthropology, at the time an especially lively place to be. He was on the rise, and continued to produce at an astonishing rate for the rest of his life. But to paraphrase Marx, people make their own history, but they don't make the conditions under which it is made. And it is these conditions that make Ben's choices both meaningful and remarkable.

The Approaches volume was, not surprisingly, dominated by older men, most of whom were born about 1918 
and were in the twilight of their careers. Many of them were to participate in the next stage of the theory drama. Their efforts were designed to continue their hegemony into the next generation, an effort thwarted by the fact that their students had rebelled against them. Harriett Zuckerman, Merton's wife, recalled the late 1960s and 70s as the "killing the fathers" period, and it clearly caused Merton himself great pain. In his correspondence one finds both enraged but unsent replies to youthful critics who had written to him, and careful corrections mixed with barely muted anger of the interpretations even of his sympathizers when they verged on criticism. Parsons died in 1979 , but in his last years did nothing to conceal his disdain for the young, or at least the vast majority of the young, who regarded him as toxic. I gave a paper at a workshop for the theory section of the ASA in the Montreal meeting (with a Presidential address by Peter Blau) that followed the World Congress. When I quoted Levi-Strauss, Parsons, who, astonishingly, was in attendance, shouted out "bullshit."

We were looking elsewhere for inspiration. The reaction to our leaving the reservation was brutal. No departure from orthodoxy, it seemed, even by the lowliest graduate student from the most obscure university, was too small to be assailed. This was just the open disdain: the real warfare was in the trenches of reviewing. The entirely unobjectionable book I published with Regis Factor on the reception history of the fact-value distinction (1984) was originally submitted to Cambridge, where I had published already (not without the drama of having to discredit a hostile referee, which the editor, Robin Williams, had the grace and decency to overrule), and the first review was ecstatic. The second review was unremittingly hostile, accusing us of ideological sins we had never heard of. They sorrowfully rejected it. The same sequence was repeated at the University of Massachusetts, with the same result. This story was repeated over and over for all of us, and it is what forced Ben to publish where he did.

This was all hidden in the cloak of editorial secrecy. The public instrument of the cabal's revenge was Jeff Alexander, and his carefully orchestrated emergence as a star, author of a four-volume magnum opus entitled Theoretical Logic in Sociology (1983-4), with volumes on something like the philosophy of science, Marx, Weber, Durkheim, and Parsons, the new protective canon. For those who did not live through this event, I will try to capture its impact. Alexander was only a few years older than we were, and certainly of the same generation. Both of us had Ph.D.'s before his, in 1978. Before this work, he had not published much - an ASR article on Parsons, and three or four other pieces in much less central journals. Ben had published much more than Alexander, and it must be said, was rewarded for it with an appointment to Buffalo, a department which was congenial both to theory and radicalism, and in which he flourished. But the emergence of Alexander changed the circumstances, or showed how they had already begun to change.

One can imagine the shock, when entering the ASA annual meeting book exhibits, of seeing large placards proclaiming the arrival of a new theoretical messiah. The dead hands of the recent past were laid on Alexander like an apostolic succession. The dust jackets for these books have probably long disappeared from the library shelves, but a few quotations can give the flavor. Daniel Bell opined that the book had "magisterial range" and that "we may yet have here a new master in the offing." Seymour Martin Lipset, from the Merton side, said that "there can be no question that Alexander's book is both brilliant and original." Alvin Gouldner wrote that "The publication of this work will be a major event in the lives of American Sociologists," Lewis Coser that "The man reads and writes with enormous sophistication, lucidity, and theoretical penetration." There were many more in the same vein, by the same crowd.

In retrospect, the praise and the brazenness of the promotion of these books reeks of a kind of desperation. But it was also an in your face act of revenge for a decade and a half of criticism and rejection. I had my share in this criticism, and the rejection was deserved. There had been flashes of insight and even brilliance in the generation that was passing. But the bad ideas and scholarly horrors outweighed the good. Needless to say, they were not amused when the younger generation began to pick these works apart. But they still had power, the power of a cabal, and they used it. They used it, in the end, to burn the house of theory down. Alexander's volumes did not spark a renaissance. Instead they were brutally critiqued by his contemporaries, and his ambition to be "Parsons, Jr," (1983) as Alan Sica entitled his AJS review, was derided. But there was another consequence. The Approaches volume was theory from the commanding heights, theory that every sociologist was supposed to have a stake in, know, respect, and use, as the core of the discipline. From the 1980s on, there was a successful attempt, starting at the top of the discipline, to marginalize theory and, as I have documented elsewhere (2012), to de-intellectualize the discipline.

John Levi Martin is our witness to this act of defenestration. He explains how theorist theory, or what he calls "theory-ology," the business of critical engagement with other theorists, become the kind of "theory that we all hate." He notes that 
at one time it was common for every theory department to have 'a' theorist... But by the time I left school there had been a clear shift in hiring procedures in graduate departments, which stopped thinking they need 'a' theorist, and started thinking that someone who was smart and well-educated in theory, even if she was more closely associated with an empirical research program, would be preferred. $(2015,2)$

The new mantra was that "Theory is too important to be left to the so-called theorists, along with "we are all theorists" $(2015,3)$. The idea, as he explains, "was to put a stop to theory-ology," i.e., the study and critique of theorists for its own sake, to reduce the social distance from theorist (i.e., their status), and to put down epistemic criticism in favor of "the prevailing epistemic understanding ... that was common to mainstream sociology in the eighties" $(2015,4)$.

In the 1970s, it still seemed that the hard but right path for someone like Ben was replacing the cabal and its works with a better, more open, and more Millsian sociological theory. But this assumed that theory would retain its status in the profession and that it was also something that could be presented to "the public." As the younger generation gained in stature through their works, they discovered that this was wrong. The citadel was empty, but no one cared about theory, at least in the traditional high-status departments of sociology. Indeed, the disdain of the cabal had become institutionalized in the new anathema that had been pronounced on theory.

This was the situation Ben faced. He was committed to the ideas of his 1974 commentary on the World Congress. But sociology could no longer be, as it was for Mills, a straightforward vehicle for these commitments. Ben could have gone elsewhere, and bracketed academic sociology. In a sense, in the end of his career, he did. But much of his work reflected a commitment to the idea of sociology rather than real-existing (and increasingly depressing) sociology, and with the world that sociological thinking had created: he was concerned with the sociological construction of reality, in such books as Socio(onto)logy (1989), and with the prospects of reforming sociology to speak again to the public, as in Public Sociology (2000).

What were his options? The roads he did not take included a kind of Marxism that briefly flourished in the 1970 s and 80 s in which the idea of the proletariat was to be saved by casuistical analyses of new class fractions. He did not, as many did, simply join the specialist historical communities that still cared about Durkheim and Weber and engaged in the thankless (certainly thankless to sociology) task of cleaning the Augean stables of bad interpretation left over from the Parsons-Merton era. Nor did he turn to epistemic critique, which was not only equally thankless and disdained, but which had the added disability of being a waste of intellectual effort: the subjects of the critiques, people like Blau, had made their errors out of incompetence and arrogance, the same attributes that prevented them from understanding and responding to the critiques. Moreover, the errors were so bizarre and convoluted that it was difficult to extract general lessons from the activity of critique. Nor did he choose the one path that could lead to professional success: to become the mouthpiece of one or another European theorist or movement. Nor did he give up, as so many did, including many one-hit wonders, people who had done some good work, but didn't have the heart to continue.

Engagement was another problem. It is something of an oddity, but on reflection not surprising, that many of the people in this situation who sought an engaged sociology became engaged closer to home, where they had some chance of making an impact: in university administration. Ben took on enormous responsibilities at Buffalo, ultimately serving as Chair. He was an institution builder and contributor his whole career. His editing work endures.

So, of course, does his published work. Unlike some of those who sold out and conformed to the new reduced model of theory, he produced continuously, expanded his horizons, used literary theory as a sword, responded to the feminist revolution, and stayed the course. His citations exceed those of some prominent "theorists" by more than an order of magnitude. He arose from the wreckage and prevailed. He found an audience, despite the fact that the audience had vanished from sociology. And in all this he held to the path he had hoped sociology would take when he wrote on the 1974 World Congress.

Pouring one's life out in the service of an ideal has a certain nobility apart from the way the world responds. Ben lived the theoretical life. There were few who could be counted as his peers in this respect. He never flagged, and never gave in. And it worked. He also kept his sense of humor and proportion. When William Outhwaite and I prevailed on him to write a chapter for a methodology book (2007) he was greatly amused, and said "wait until I tell my colleagues I am in a handbook on methodology." It was his character, this character, that preserved him and allowed him to flourish intellectually, as a servant of the world, and as a human being, during a time that was, for many people, a time of disillusion. 


\section{References}

Agger, Ben. 1972. "Of Style and Speech in the New Age." First International Conference on Participation and SelfManagement, Dubrovnik, Yugoslavia.

Agger, Be. 1989. Socio(onto)logy: A Disciplinary Reading. Urbana, IL: University of Illinois Press.

Agger, Ben. 2000. Public Sociology: From Social Facts to Literary Acts. Lanham. MD: Rowman \& Littlefield.

Alexander, Jeffrey C. (1982-3) Theoretical Logic in Sociology, 4 vols. Berkeley and Los Angeles: University of California Press.

Blau, Peter. 1975. Approaches to the Study of Social Structure. New York: The Free Press.

Martin, John Levi. 2015. Thinking through Theory. New York: Norton.

Merton, Robert. 1975. Structural Analysis in Sociology. In Approaches to the Study of Social Structure, edited by Peter M. Blau. New York: Free Press, pp. 21-52.

Outhwaite, William and Stephen Turner. 2007. The Sage Handbook of Social Science Methodology 1st edn. London: Sage.

Sica, Alan. 1983. "Parsons, Jr." Reviewed Work: Theoretical Logic in Sociology. Vol. 1: Positivism, Presuppositions, and Current Controversies by Jeffrey C. Alexander. American Journal of Sociology 89(1): 200-219.
Turner, Stephen and Regis Factor. 1984. Max Weber and the Dispute over Reason and Value: A Study in Philosophy, Ethics, and Politics. London: Routledge \& Kegan Paul, Ltd.

Turner, Stephen. 2012. "Deintellectualizing American Sociology: A History, of Sorts." Journal of Sociology 48(4): 346-363. doi: $10.1177 / 1440783312458226$ 